\title{
Psychology and spirituality: is there a place on the Couch for transcendence?
}

\author{
Psicologia e espiritualidade: existe espaço no divã para a transcendência? \\ Psicología y espiritualidad: existe espacio en el diván para la transcendencia? \\ Rosimar José de Lima Dias ${ }^{l}$ \\ Illinois School of Professional Psychology, Argosy University, Schaumburg Campus
}

\begin{abstract}
Resumo
Embora psicologia e espiritualidade possam parecer duas áreas bastante diferentes à primeira vista, é possível constatar inúmeros pontos de convergência e formas de integração destes dois campos do conhecimento. Desde uma perspectiva clínica, parece válido o esforço de explorar espiritualidade e o entrelaçamento da mesma com saúde mental, como forma de se ter uma compreensão mais integrada do funcionamento de clientes e de se proporcionar aos mesmos um processo psicoterapêutico mais holístico. Tal abordagem pode permitir que indivíduos superem a enraizada tendência ocidental de se perceber os seres humanos como tendo estanques ou dualistas dimensões. O objetivo deste artigo é abordar espiritualidade através da teoria das relações objetuais e propor um possível caminho para integrar espiritualidade no cenário psicoterapêutico, considerando os estágios do desenvolvimento do ego e discutindo um modelo de desenvolvimento de espiritualidade. Por fim, são apontadas algumas possíveis implicações e benefícios clínicos resultantes de se permitir espaço para transcendência no "divã".

Palavras-chave: Relações objetuais; Espiritualidade; Teoria do apego; Transcendência; Desenvolvimento do ego.
\end{abstract}

\begin{abstract}
Even though psychology and spirituality may appear at first glance as two quite different fields, it is possible to find innumerous points of convergence and ways of integration in these fields. From a clinical perspective it seems a worthwhile endeavor to explore spirituality and its interweaving with mental health to have a more integrative comprehension of clients' functioning and to deliver psychotherapy in a more holistic way. This approach may allow individuals to overcome a rooted Western tendency of viewing human beings as having compartmentalized or dualistic dimensions. The goal of this paper is to approach spirituality through object relations theory and to propose one possible way to integrate spirituality in the psychotherapeutic setting, considering ego developmental stages and discussing a developmental model of spirituality. Finally, some possible clinical implications and benefits are pointed out as a result of making room available for transcendence on the "couch".

Key-words: Object relations; Spirituality; Attachment; Transcendence; Ego development.
\end{abstract}

\begin{abstract}
Resumen
Aunque la psicología y la espiritualidad a primera vista puede aparecer que son dos campos muy diferentes, es posible encontrar un sinnúmero de puntos y maneras en común de integrar estos campos. Desde una perspectiva clínica, parece un valido esfuerzo explorar como la espiritualidad se entrelaza con la salud mental para tener una comprensión integrativa de como los clientes funcionan y proveer psicoterapia en una manera mas holística. Esta manera hará posible que los individuos sobrepasen la tendencia occidental muy arraigada de ver a los humanos de una manera compartimentada o de una dimensión dualística. La meta de este artículo es abordar a la espiritualidad a través de la teoría de las relaciones de objeto y proponer una posible manera de integrar la espiritualidad en la psicoterapia, considerando las etapas del desarrollo del ego y discutir un modelo del desarrollo spiritual. Por último, algunas implicaciones clínicas y beneficios son discutidos como resultado en crear un espacio en el "sofá" para la transcendencia.
\end{abstract}

Palabras-clave: Relaciones de objeto; Espiritualidad; Teoría del apego; Transcendencia; Desarrollo del ego.

\section{Psychology and Spirituality: Is There Room on the Couch for Transcendence?}

Western culture has a tendency to compartmentalize things such as mental versus physical illness, soul versus body, science versus religion, theory versus practice, spirituality versus psychology, black versus white; forgetting that greyish shadows usually make a picture more appreciable. However, when a

Endereço 1: 211 Austin Lane, Apt. 207 - Schaumburg, IL 60195 USA. Fone: +1 (224) 500-0719 psychotherapist has an individual client who is not so individualized, due to many contributing factors in the construction of the self, such compartmentalization is neither helpful nor natural. It is not helpful since more integrated individuals are less dysfunctional and less immature. Nor is it natural because people tend to function holistically; thus, occupational, relational, spiritual, and psychological domains tend to interweave and influence one another reciprocally.

From a clinical perspective it seems a worthwhile endeavor, for both practitioners and clients, to explore spirituality and its interweaving with emotional, 
physical, and mental health to have a more integrative comprehension of client functioning. This allows the individual to overcome a compartmentalized perception of life. Such a proposal would necessarily include addressing, assessing, understanding, and appreciating the meaning of spirituality in the context of psychotherapy.

Nonetheless, spirituality is frequently relegated to the shaman, the priest, the rabbi, the imam, or other spiritual leaders, which keeps it somewhat unexplored and underutilized in psychotherapy. Indeed, someone could argue that the scientific realm would not be able to investigate and explain such a phenomenon as spirituality or religiousness since it is not rooted in measurable variables. Nevertheless, according to Kirkpatrick's (2005) metaphor, no one would expect an exhaustive explanation of Leonardo da Vinci's artwork via thorough dissection of the canvas, and analysis of the paint and brush techniques because it would be mere ontological reduction. That is to say a psychological appreciation of spirituality and religiousness should make the effort to go beyond mere ontological reductionism and contemplate the whole picture. Such a perspective may reveal spirituality as a fecund field to be explored from psychological lenses. According to a recent review (Hefti, 2011), a growing body of evidence has highlighted favorable effects and a real demand for such an integrative perspective, which can occur through a variety of themes and approaches.

As a matter of challenging the impelling Western tendency of compartmentalization, the primary goal of this paper is to approach spirituality through object relations theory as a way to integrate spirituality in the psychotherapeutic setting. Further, this article also aims to constitute a small contribution to the psychology of religion, which is still considered an underdeveloped subfield of psychology when compared to other subfields such as clinical psychology, social psychology, and health psychology (Emmons \& Paloutzian, 2003). Although there has been significant growth on research in the psychology of religion that is tied to almost every area of research in general psychology, only a portion of the field has begun to incorporate the knowledge from the psychology of religion into its own information base and practices (Emmons \& Paloutzian, 2003). Therefore, the second goal of this article is to modestly contribute to the integration of psychology of religion research into psychotherapy.

\section{Defining Key Terms}

An integration of the psychology and spirituality would be deficient without a clear definition of the guiding terms of this paper, that is, spirituality and object relations. In fact, an authentic dialogue can only be established after making clear both speakers are speaking the same language.

\section{Spirituality}

Psychotherapists outside the specialized discipline of psychology of religion often understand religious/ spiritual beliefs as a unitary aspect of individual differences. However, laypersons seem able to recognize distinct vectors in such beliefs (Zinnbauer et al., 1997). Although a growing number of individuals in Brazil claim no religious affiliation, approximately $95 \%$ of this unaffiliated group still believe in God (Instituto Brasileiro de Geografia e Estatística, 2010), and may consider themselves as spiritual but not religious. Actually, the statement "spiritual but not religious" forms the title of a scholarly book (Fuller, 2001) that discusses contemporary metaphysical religion and "unchurched," eclectic, and "psychological" spirituality.

Consequently, understanding the difference between religiousness and spirituality is growing in both conceptual and methodological importance (Aldwin, Park, Jeong, \& Nath, 2014). In studies of the effects of religiousness, spirituality, and health, religiousness is often assessed through simple measures of affiliation or service attendance, while spirituality is generally assessed as feelings of closeness to God and self-transcendence and/ or as engagement in practices such as meditation or mindfulness (Fetzer Insitute/National Institute on Aging Working Group, 1999).

Nevertheless, numerous definitions of religiousness can be found in the psychological literature. There are concrete, abstract, metaphysical, prescriptive, relationship-oriented, inner-motivationoriented, and existential-quest-oriented definitions (Zinnbauer, Pargament, \& Scott, 1999). Argyle and Beit-Hallahmi (1975) defined religion as "a system of beliefs in a divine or superhuman power, and practices of worship or other rituals directed towards such a power" (p. 1). The emphasis this definition places on worship and rituals implies community activity that binds or ties people together. Indeed, such an understanding of religion favors one of the two most common etymologies of this word found in ancient authors. According to Aiken (1911), the origin of the term "religion" goes back to Cicero and Lactantius. While in Cicero's writings religion is derived from the Latin verb relegere (i.e., to go over again in reading, speech, or thought; to treat carefully), in Lactantius' texts "religion" comes from the Latin verb religare (i.e., to bind, to tie up) (Aiken, 1911). Medieval authors such as Augustine and Thomas Aquinas ultimately favored Lactantius's comprehension of religion, which seems to capture much of what religion has become in its simplest form across different modern Western cultures. Such a notion of religion implies the idea of being bound to, having a personal relationship with, and voluntary subjection to a transcendent being (Aiken, 1911). Further, it encompasses a set of beliefs, practices, and 
body of doctrines with a certain number of adherents who generally perceive themselves as motivated by faith. Obviously this definition of religion inherited from medieval authors is strongly rooted in the Judeo Christian tradition and certainly neglects the cultural, sociological, and historical multiplicity of the religious phenomenon. However, it serves the purpose at hand of providing a basic definition of religion, which is necessary in order to illustrate how the terms religion and spirituality are not necessarily interchangeable.

Definitions of spirituality, on the other hand, usually put more emphasis on the individual and on subjective experiences. The word spirituality comes from the Latin word spiritus, which in turn comes from spirare (to breathe; Wulff, 1997). Shafranske and Gorsuch (1984) defined spirituality, broadly, as "a transcendent dimension within human experience (...) discovered in moments in which the individual questions the meaning of personal existence and attempts to place the self within a broader ontological context" (p. 231). Vaughan (1991) provided a useful, more specific, definition: "a subjective experience of the sacred" (p. 105). Emmons (1999) pointed out spirituality may be related to religiousness in some contexts, but this may not always be the case. For Emmons, spirituality involves "a search for meaning, unity, connectedness to nature, humanity, and the transcendent" (1999, p. 877), thus having a strong subjective element.

In any case, developing satisfactory definitions of religiousness and spirituality has been the goal of a multitude of theorists and researchers over the past two decades (Oman, 2013). In spite of these efforts, the goal remains elusive, as any definitions of religiousness and spirituality (and any distinction drawn between them) generate dissention and lead others to try once again. This article will follow the lead of a recent proposal by Pargament, Mahoney, Exline, Jones, and Shafranske (2013) in their introduction to APA Handbook of Psychology, Religion, and Spirituality. They defined spirituality as "the search for the sacred," with sacred referring not only to God or higher powers, but also to "other aspects of life that are perceived to be manifestations of the divine or imbued with divine-like qualities, such as transcendence, immanence, boundlessness and ultimacy" (Pargament et al., 2013, p. 14). In contrast, they defined religion as "the search for significance that occurs within the context of established institutions that are designed to facilitate spirituality" (Pargament et al., 2013, p. 15). Note that spirituality often occurs in the context of religion, but it also can occur outside of traditional religious boundaries (Zinnbauer \& Pargament, 2005)

Although spirituality and religiousness may have complimentary aspects, the term spirituality will be preferred throughout this paper because it seems to be a broader and more inclusive construct. Indeed, this approach seems opportune because it takes into consideration readers who consider themselves as "spiritual but not religious." However, it is important to notice that, even though the definition of spirituality is broader and more inclusive than religiousness, it is still limited by the notion of transcendence and search for the sacred based in an intersubjective relationship, which may encompass Judeo Christian values that may not be shared by other types of spiritualty. In line with this notion of spirituality, it is assumed human beings have the capacity to go beyond themselves and their daily struggles in search for transcendence and not just strive for natural goods (economic, political, social, and so on). This fundamental capacity within the human person is here understood as ability for self-transcendence, which is evoked by the word transcendence on the subtitle of this article.

Howsoever, the distinction made here and the decision to use the construct spirituality instead of an interchangeable use of religiousness and spirituality is more for a matter of being inclusive than for compartmentalization intent. Actually, some readers especially those who consider themselves as religious individuals - may find opportune to integrate both constructs and this is perfectly fine.

\section{Object Relations Theory}

The object relations approach emerged out of psychoanalytic theory and had its inception from understanding that early relationships impact human development and psychological well-being. Object relations approach understands relatedness and mutuality as basic motivators for human behavior. Internalized images from relations with past significant others, especially caregivers, result in object representations which are then projected onto current relationships, particularly when individuals somehow stir up one's response to prior relationships (McDargh, 1983; Mirman, 2012; Wenar \& Kerig, 2005). Relying on these prior relationships, individuals form ideas and perceptions about themselves. The social construct called self is the product of these selfimages. If individuals experience a nurturing and protective childhood they will develop more accurate views about themselves, their strengths, and their weaknesses. Conversely, experiencing conditional love and poor caregiving generates inaccurate perceptions of oneself that can impact psychological well-being and current relationships.

This unfolds through three developmental stages of ego functioning: symbiosis, differentiation, and individuation/rapprochement (Mahler, Pine, and Bergman, 2000). The symbiotic stage is featured by dependence on the caregiver as the object for satisfying the infant's basic needs. The infant in this stage neither makes distinction nor is aware of boundaries between himself or herself and the external 
world. This includes the caregiver, who is perceived in this first stage as inherently good and unthreatening (McDargh, 1983).

The second stage, which begins around six months of age, is characterized by differentiation and splitting. It results from the caregiver's unavoidable failure to completely satisfy the infant's needs. Such needs are often delayed due to other duties the caregiver must fulfill in his or her daily life. As a result, frustration emerges and the child begins acquiring awareness of separateness related to the caregiver and external world. Consciousness is somewhat manifested in this stage because the self, facing good and bad features of the separated caregiver, is forced to recognize and accept both aspects of the caregiver, therefore establishing a new relationship with the caregiver (Mahler et al., 2000). This new relationship can be either functional or dysfunctional to the extent the child perceives the caregiver's attitude of rejection and abandonment or acquires a more realistic psychological representation that integrates the caregiver's separateness and polarity. This last alternative is a necessary condition to the development of the next stage.

In the third stage, individuation/rapprochement, the child is able to acknowledge and accept the caregiver's uniqueness and identity. Here the child is able to assimilate an internal representation about himself or herself and others and the goodbad polarities are integrated into this representation (Mahler et al., 2000). Accordingly, the child gives up a representation of the caregiver as an omnipotent entity and displaces it with a representation that aggregates the caregiver's ambiguity, complexity, and individuality.

Individuals' psychological functioning increases to the extent that they are able to efficaciously achieve separation and differentiation, internalizing psychological representations of themselves and others that are more accurate and integrated. Thus, caregivers play a significant role in this process, such that their ability to provide a safe, nurturing and supportive environment not only promotes, but also softens significantly the separation and individuation process.

In contrast, poor relationships, abusive parents, threatening, and unstable environments may leave lasting psychological sequelae such as splitting of the self, continuous sense of worthlessness, powerlessness, and incompetence. This may lead the individual to replay the dysfunctional relationship pattern in future relationships. Since the psychological drama had its origin in an unhealthy relationship, the healing process goes through a warm and empathic relationship, which can be found in a therapeutic setting. Indeed, the psychotherapeutic goal in the object-relational framework is to break the maladaptive relationship template. This is accomplished through remodeling the dysfunctional relationship pattern and helping the individual become aware of the maladjusted template. The individual is assisted by the therapist to develop and replay, in a therapeutic setting, a healthier relationship template and generalize this new template to real situations.

\section{From Object Relation Stages to an Ego Developmental Blueprint}

Considering the theory of object relations and its developmental conception of ego, Mirman (2012) proposed a developmental model of spirituality based on three stages as well: primary or defenseless, secondary or defensive, and transcendent or nondefensive. It is important to keep in mind from the beginning that individuals can experience these stages not only progressively throughout their spiritual process of development, but also carry them into adulthood in alternate fashion, sometimes progressing, and at times regressing, in continuous struggle.

Individuals who dwell in, or are more prone to stay in, the primary or defenseless stage usually have a primitive, fragmented, and fragile ego (Mirman, 2012). Moreover, according to Mirman, characteristics such as innocence, timelessness, powerlessness, defenselessness, and separateness are easily observed in these individuals. Although they have a sense of awe and wonder, it does not indicate spiritual maturity but rather lack of insight and inability to transcend. Further, since the world is a new reality, they experience it as magic and mysterious (Mirman, 2012).

The secondary, or defensive stage, houses individuals who are strongly grounded who tend to accumulate supplies, both material and psychological (usually narcissistic supplies), as consequent need to defend themselves from the perceived threatening and demanding external world, and from the good and bad polarities of others. Therefore, the ego in this stage is markedly materialistic, self-oriented, and rigid. Moreover, there is great tendency to be controlling, on guard, cynical, and slave to time and agendas (Mirman, 2012). According to Mirman, people in this state usually see the world as predictable, knowable, controllable, and ordinary.

The last stage, named non-defensive or transcendent, can be described as the stage to which individuals overcome the ego rigidity of the defensive stage and are able to experience a sense of freedom, gratitude, love, and openness to inner experiences (Mirman, 2012). According to Mirman (2005, p. 4344),

The yearning to return to a younger, nondefensive way of being - to recapture lost innocence, to experience awe, wonder and a sense of the sacred, and to feel the sense of being part of something larger than one's own "skin-encapsulated 'I"' (Watts, 1969) - is universal.

Additionally, the ego here is featured by non- 
defensiveness, maturity, flexibility, transcendence, receptiveness, timelessness, trustworthiness, and openness (Mirman, 2012). Besides having an attitude of faith, another meaningful imprint of individuals who attain this stage is proactive love, contrasting to those in the previous stage who long for being loved (Mirman, 2012).

According to Mirman (2012), people are continuously struggling to avoid regressing to the first stage because they fear being defenseless and are not willing to give up the sense of security acquired in the second stage. They maintain themselves tightly on guard, which prevents experiencing the spiritual joyfulness and sense of fulfillment that can be reached in the transcendent stage.

Actually, this basic internal dialectic that can be observed in each human being, is not solely due to cultural and personal characteristics, but is also ontological, constitutional, and intrinsic to individuals' motivational system (Rulla, 1987). Therefore, one of the most peculiar features of the human being is yearning to be challenged by something that goes beyond their narrowness; their finiteness. This yearning for the infinite surrounds the human being without annihilating the finite that exists in him is properly fulfilled when they give up material security and dare to embark in the selftranscendent consistency process. According to Dias (2010), this process consists of an ongoing attempt to overcome the actual self (which tends to be markedly rigid) as a means to realize the ideal self (that should be receptive and proactive). This is accomplished through the process of internalization of transcendent values such as openness, proactive love, gratitude, and faithfulness.

\section{Enhancing Meaningful Relationships}

An emphasis on relationships underlies both spirituality and object relations theory. In fact, one of the aspects that pervade the definition of spirituality is a relationship with a perceived transcendent being. In addition, spirituality usually encompasses the unique idea of searching for the sacred (Pargament, 1999), or searching for relatedness that goes beyond oneself, which manifests desire for separateness, transcending the here-and-now, and culminating in the I-Thou (Ich und Du) relationship (Buber, 1986). In Buber's relational model of spirituality the "I" is the conscious self and the "Thou" is the other or the transcendent being that can only be known through relational involvement (Hill \& Hall, 2002). A spiritual individual usually perceives this transcendent being as something beyond consciousness and materiality.

Likewise, object relations theory places relationship as a core element on its comprehension of human development. To put it differently, the object relation perspective, the way relatedness and attachment unfolds and how the individual perceives himself or herself and others are fundamental sources of internal motivation (Hansen, 2000). These meaningful patterns are internalized, reinforced, and replayed throughout adulthood. In sum, human beings are primarily driven by internalized patterns of interpersonal relationships, and seek interpersonal connections as a general rule.

Therefore, the I-Thou, or relatedness experience, is a strong point of convergence for both spirituality and object relations theory. Such a reality is a mysterious and dynamic experience to be achieved, a goal to be pursued, and yet a driving force to be guided by. Paradoxically it comes from within the self, but is satisfied thru self-transcendence.

\section{Strengthening Attachment Bonds}

Attachment theory, combined with the human relatedness experience and demand for relationships, seems to be closely linked to the basic source of human motivation proposed by the object relations theory. According to Bowlby (1988), children develop an internal working model that encompasses either a confident and secure attachment (resulting from proximity and centrality) or anxious, insecure attachment (founded on caregiver's unavailability and inconsistency). Consequently, attachment style contributes to individuals' development of sense of self, such that a confident and secure attachment results in a competent, skillful, and healthy self. An anxious and insecure attachment leads to poor self-esteem and unsteady sense of self. According to Krause and Haverkamp (1996), the developed internal working model during infancy, either secure or insecure, tends to persist throughout the individuals' life and serve as a model for their future relationships.

Similarly, the quality of relatedness with a transcendent being may either outline the internalized individual representations, or be modeled by individual attachment bonds. According to Rizzuto (1979), from the object relations understanding of spirituality, there are two types of transference: (1) correspondence, that is, individuals unconsciously arrange their relations with others corresponding with how they unconsciously experience the sacred; or (2) compensatory, which means, individuals perceive spirituality as a compensatory object, something yearned for but never fully experienced. Building on this notion of transference and spirituality, Kirkpatrick (2005) stated an individuals'blueprint for relations with a transcendent being as an attachment figure may be featured either by the correspondence hypothesis or by the compensation hypothesis. In the correspondence hypothesis an individual's relationship to the transcendent being is similar to his or her relationship to the caregiver. In the compensation hypothesis, an individual's relationship to the transcendent being is a substitute for his or her relationship to the caregiver. This last hypothesis may explain reported findings 
that people with inadequate object relations history are more prone for religiousness (Kirkpatrick \& Shaver, 1990). Particularly, because the sacred may symbolize the idealized attachment image and work in compensatory fashion for people with avoidant or inconsistent attachment bonds.

Hill and Hall (2002) emphasized an individual's internalized representation of the sacred or the divine assists them in deepening the sense of who they are. Using object relations language, the purpose in life, the belief in a vital force that provides vigor and a sense to the material realm, and the feeling of being loved by a transcendent being, enhance the development of a secure and confident internal working model. This seems to be especially noticeable in individuals who perceive the relationship with the transcendent being as an attachment relationship featured by proximity and centrality.

Indeed, Loewenthal (1995) stated religious adults tend to report more consistent coping abilities, more adaptive stress management, greater sense of personal efficacy, and sounder feelings of social support than nonreligious ones. A recent literature review found spirituality and religion may help individuals improve emotional adjustment, maintain purpose, hope, and meaning of life (Hefti, 2011). According to Kirkpatrick (2005), religiousness is facilitated by social and psychological mechanisms of attachment, partnership formation, social exchange, and mutual altruism. A constructive relationship with a transcendent being may provide feelings of comfort, security, sense of belonging, partnership, and alliance (Hill \& Hall, 2002).

\section{Clinical Implications and Final Considerations}

Even though many clients wish for clinicians to address spirituality and religiousness during psychotherapy (D'Souza, 2002), they usually manifest two main concerns about addressing it in a clinical setting: (1) the fear their spiritual beliefs could be reduced or trivialized by the clinician; or (2) the concern their beliefs and spiritual experiences could be regarded as symptoms of psychopathology. Therefore, when treating clients with strong spiritual and religious backgrounds, clinicians should display a respectful attitude regarding clients' unique experiences and make an effort to integrate spirituality into the psychotherapeutic process whenever it is beneficial to improve their psychological functioning.

It is firmly established within the scientific literature that religiousness and spirituality are associated with both mental and physical health (see Koenig, 2008; Levin, Chatters, \& Joseph, 2011). In general, the effects tend to be positive, including lower levels of psychological distress and depressive symptoms, better health-related quality of life, and decreased morbidity and mortality (Masters \& Hooker, 2013; Park \& Slattery, 2013). Therefore, appreciating and incorporating clients' religiousness and spirituality in the clinical setting may enhance their mental and physical health.

Assessing clients' spiritual representations may be a helpful instrument to identify their internal working model and opportune in understanding their ego stage of development. Indeed, individuals whose internalized representations are less functional tend to have more dysfunctional relationships on a spiritual level. For instance, a client who is more inclined to please others may feel more compelled to please the divine, due to an unconscious defense against rejection. Conversely, one who perceives others as insensitive, critical, and aloof may have this same perception regarding the transcendent being (Hill \& Hall, 2002). Perhaps this explains Kirkpatrick and Shaver's (1992) observation that individuals who experienced avoidant attachment lean more towards agnosticism, while those whose attachment history was marked by ambivalence and anxiety display more atheistic and antireligious preferences.

Several aspects need to be considered in the challenging task of integrating spirituality into psychotherapy. For instance, being able to assess and understand the ways in which spiritual expressions may enhance or impair psychological functioning, developing skills to address spirituality without intrusiveness or reductionism, and being aware of counter transference that may occur due to the clinician's own spiritual/religious experiences or bias (Koenig, 2002) are key areas the clinician should be aware of. Additionally, psychotherapists should be aware that regardless of the nature of transference, it is actually the feelings, thoughts, and experiences that surface from initial relationships, and those that result from clients" "search for the sacred" (Pargament, 1999) that are useful as archetype and relational blueprint.

Client's self-perception and consequent ability for self-transcendence is another clinical implication that can be drawn by assessing and understanding his or her spiritual relationship blueprint through object relation lens. Individuals who experience the transcendent being as sensitive, affectionate, and compassionate will be more inclined to perceive themselves in a more holistic way, more open to others, and more able to give up defensiveness towards self-transcendence. Conversely, individuals who experience the divine as demanding, punitive, and retributive will be more legalistic, restrictive, and rooted in defensiveness. Such individuals may be excessively preoccupied with the letter of the law, religious dogmas, and rules of conduct, rather than with the spirit of the law, mercifulness, and compassion. In addition, these individuals may lack the openness to establish an indepth therapeutic alliance. Consequently, they may be more resistant to engage in the psychotherapeutic process that would allow them to experience a sense 
of profound freedom and enjoyment that are relished by those who assume the priceless gift of selftranscendence day-by-day.

Finally, even with those apparently more resistant, the psychotherapist should assist them with a warm and empathic therapeutic relationship, offering his/ her "couch" as a safe, nurturing, and supportive environment by which they may be challenged to reach self-transcendence and enhance psychological well being. Putting this in a metaphor, a psychotherapeutic environment should work as a safe harbor in which individuals can anchor themselves to reframe or remodel relational blueprints in order to move to deeper waters of an authentic experience of consistent self-transcendence.

\section{References}

Aiken, C.F. (1911). Religion. In The Catholic Encyclopedia. New York: Robert Appleton Company.

Aldwin, C. M., Park, C. L., Jeong, Y., \& Nath, R. (2014). Differing pathways between religiousness, spirituality, and health: A self-regulation perspective. Psychology of Religion and Spirituality, 6(1), 9-21. doi: 10.1037/a0034416

Argyle, M., \& Beit-Hallahmi, B. (1975). The social psychology of religion. London: Routledge.

Bowlby, J. (1988). A secure base: Parent-child attachment and healthy human development. New York, NY: Basic Books.

Buber, M. (1986). I and Thou. New York, NY: Scribner.

D'Souza, R. (2002). Do patients expect psychiatrists to be interested in spiritual issues? Australasian Psychiatry, 10 (1), 4447. doi:10.1046/j.1440-1665.2002.00391.x

Dias, R. J. L. (2010). Psicologia do profundo e formação sacerdotal: Estudo aplicativo da teoria da "autotranscendência na consistência" de Luigi M. Rulla, sj. (Dissertação de Mestrado, Universidade Católica Dom Bosco, Campo Grande, MS). Retrieved from http://www3.ucdb.br/mestrados/arquivos/dissert/651.pdf.

Emmons, R. A. (1999). Religion in the psychology of personality: An introduction. Journal of Personality, 67, 873-888.

Emmons, R. A., \& Paloutzian, R. F. (2003). The psychology of religion. Annual Review of Psychology, 54, 377-402.

Fetzer Institute/National Institute on Aging Working Group (1999). Multidimensional measurement of religiousness, spirituality for use in health research. Retrieved from http:// www.fetzer.org/ resources/multidimensional- measurementreligiousnessspirituality-use-health-research.

Fuller, R. C. (2001). Spiritual, but not religious: Understanding unchurched America. Oxford: Oxford University Press.

Hansen, J. T. (2000). Psychoanalysis and humanism: A review and critical examination of integrationist efforts with some proposed resolutions. Journal of Counseling \& Development, 78 (1), 21-28. doi:10.1002/j.1556-6676.2000.tb02556.x.

Hefti, R. (2011). Integrating religion and spirituality into mental health care, psychiatry and psychotherapy. Religions, 2 (4), 611-627; doi:10.3390/rel2040611.

Hill, P. C., \& Hall, T. W. (2002). Relational schemas in processing ones image of God and self. Journal of Psychology and Christianity, 21 (4), 365-373.

Instituto Brasileiro de Geografia e Estatística (2010). Censo demográfico 2010: Características gerais da população, religião e pessoas com deficiência. Retrieved from http://biblioteca.ibge.gov. br/visualizacao/periodicos/94/cd_2010_religiao_deficiencia.pdf

Kirkpatrick, L. A., \& Shaver, P. R. (1990). Attachment theory and religion: Childhood attachments, religious beliefs, and conversion. Journal for the Scientific Study of Religion, 29 (3), 315-315

Kirkpatrick, L. A., \& Shaver, P. R. (1992). An attachmenttheoretical approach to romantic love and religious belief.
Personality and Social Psychology Bulletin, 18 (3), 266-275. doi:10.1177/0146167292183002.

Kirkpatrick. L. A. (2005). Attachment, evolution, and the psychology of religion. New York, NY: The Guilford Press.

Koenig, H. G. (2002). Spirituality in patient care: Why, how, when, and what. Philadelphia, PA: Templeton Press.

Koenig, H. G. (2008). Concerns about measuring "spirituality" in research. Journal of Nervous and Mental Disease, 196, 349-355. doi:10.1097/NMD.0b013e31816ff796

Krause, A. M., \& Haverkamp, B. E. (1996). Attachment in adult child-older parent relationships: Research, theory, and practice. Journal of Counseling \& Development, 75 (2), 83-92. doi:10.1002/j.1556-6676.1996.tb02318.x.

Levin, J., Chatters, L. M., \& Joseph, R. (2011). Theory in religion, aging, and health: An overview. Journal of Religion and Health, 50, 389-406. doi:10.1007/s10943-009-9319-x

Loewenthal, K. M. (1995). Mental health and religion. London: Chapman Hall.

Mahler, M. S., Pine, F., \& Bergman, A. (2000). The psychological birth of the human infant: Symbiosis and individuation. New York, NY: Basic Books.

Masters, K. S., \& Hooker, S. A. (2013). Religion, spirituality, and health. In R. F. Paloutzian \& C. L. Park (Eds.), Handbook of the psychology of religion and spirituality (2nd ed., pp. 519-539). New York, NY: Guilford Press.

McDargh, J. (1983). Psychoanalytic object relations theory and the study of religion: On faith and the imaging of God. Washington, DC: University Press of America.

Mirman, M. C. (2005). The subjective experience of God. American Journal of Pastoral Counseling, 7 (2), 41-54. doi:10.1300/ J062v07n02_04.

Mirman, M.C. (2012). An atheist's guide to the divine: Throwing out the bathwater but keeping the baby. Research in the Social Scientific Study of Religion, 23, 171-189. doi: 10.1163/9789004229549 012

Oman, D. (2013). Religious and spirituality: Evolving meanings. In R. F. Paloutzian \& C. L. Park (Eds.), Handbook of the psychology of religion and spirituality (2nd ed., pp. 23-47). New York, NY: Guilford Press.

Pargament, K. I. (1999). The psychology of religion and spirituality? Yes and no. International Journal for the Psychology of Religion, 9 (1), 3-16. doi:10.1207/s15327582ijpr0901_2.

Pargament, K. I., Mahoney, A., Exline, J. J., Jones, J., \& Shafranske, E. (2013). Envisioning an integrative paradigm for the psychology of religion and spirituality. In K. I. Pargament (Ed.), APA handbook of psychology, religion, and spirituality (Vol. 1, pp. 3-19). Washington, DC: American Psychological Association. doi:10.1037/14046-001

Park, C. L., \& Slattery, J. (2013). Religiousness/spirituality and mental health. In R. F. Paloutzian \& C. L. Park (Eds.), Handbook of the psychology of religion and spirituality (2nd ed., pp. 540-559). New York, NY: Guilford Press.

Rizzuto, A. M. (1979). The birth of the living God. Chicago, IL: University of Chicago Press.

Rulla, L. M. (1987). Antropologia da vocação cristã: Bases interdisciplinares. São Paulo, SP: Edições Paulinas.

Shafranske, E. P., \& Gorsuch, R. L. (1984). Factors associated with the perception of spirituality in psychotherapy. Journal of Transpersonal Psychology, 16, 231-241.

Vaughan, F. (1991). Spiritual issues in psychotherapy. Journal of Transpersonal Psychology, 23, 105-119.

Wenar, C., \& Kerig, P. (2005). Developmental psychopathology: From infancy trough adolescence, (5th ed.). New York, NY: McGraw-Hill.

Wulff, D. M. (1997). Psychology of religion: Classic and contemporary (2nd ed.). New York: Wiley.

Zinnbauer, B. J., \& Pargament, K. I. (2005). Religiousness and spirituality. In R. F. Paloutzian \& C. L. Park (Eds.), Handbook of the psychology of religion and spirituality (pp. 21-42). New York, NY: Guilford Press.

Zinnbauer, B. J., Pargament, K. I., \& Scott, A. B. (1999). The emerging meanings of religiousness and spirituality: Problems and 
prospects. Journal of Personality, 67, 889-920.

Zinnbauer, B. J., Pargament, K. I., Cole, B., Rye, M. S., \& al, e. (1997). Religion and spirituality: Unfuzzying the fuzzy. Journal for the Scientific Study of Religion, 36(4), 549-564.

Recebido: 09/10/2012

Última revisão: 22/04/2014

Aceite final: 29/04/2014

Sobre o Autor:

Rosimar José de Lima Dias - Licenciado em Filosofia pela Universidade Católica Dom Bosco, Campo Grande-MS; Bacharel em Teologia pela Pontifícia Universidade Católica do Rio de Janeiro, RJ; Mestre em Psicologia pela Universidade Católica Dom Bosco, Campo Grande-MS; e Mestre em Psicologia Clínica pela Illinois School of Professional Psychology, Argosy University, Schaumburg Campus, Illinois, USA. Atualmente é doutorando em Psicologia Clínica pela Illinois School of Professional Psychology, Argosy University, Schaumburg Campus, Illinois, USA.

E-mail: rosimardias@me.com 